\title{
ELECTRONIC BANKING: ITS USE AND CHALLENGE IN NEPAL
}

\author{
Krishna Kumar Shah \\ Department of Management, TU,Thakur Ram Multiple Campus, Birgunj, Nepal \\ E-mail: associateskkshah@gmail.com
}

\begin{abstract}
Electronic banking, new strategies have become necessary in order to attract and retain existing customers, changing business environments, globalization and the advancement of information and communication technology. Despite enormous pressures for change and investment in information technology in the banking field; if these investments do not work in accordance with the principles of investment, they will fail. The available sources and studies conducted in the field, seek to find out the main factors and challenges posed in the development of electronic banking after a relatively long period of adoption in Nepal. This paper highlights the challenges for the development of e-banking, its impact of infrastructural barriers, legal and security barriers and management-banking barriers on the development of e-banking in Nepal.
\end{abstract}

\section{Key words}

E-banking; challenges; internet banking; infrastructure; legal security

\section{Introduction}

Electronic banking (e-banking) is simply the use of electronic means to transfer funds directly from one account to another, rather than by check or cash. The universal connectivity which the internet offers has made IT an invaluable business tool. These developments have created a new type of economy, which may be called the 'digital economy'. This fast emerging economy is bringing with it rapidly changing technologies, increasing knowledge intensity in all areas of business and crating virtual supply chains and new forms of business and service delivery channels such as e-banking (Shanmugan, 2003).

The term "e-banking" has been used in literature in many different ways, partially because electronic banking refers to several types of services through which banks' customers can request information and carry out most retail banking services via the internet, television or mobile phones. Generally speaking, e-banking means providing banking products and services 
directly to customers through electronic, interactive communication channels.

However, a more comprehensive and common definition for e-banking comes from the Basel Committee Report (1998) on banking supervision. The report basic defines e-banking as the provision of retail and small value banking products and services through electronic channels, such products and services can include deposit taking, lending, account management, the provision of financial advice, electronic bill payment products services such as electronic money.

Banking institutions have become an essential component of most economy whether they are described as engines for economic growth acting as conduits towards promoting economic growth (Sathye, 1999). There are not many inventions that have changed the business of banking as quickly as the e-banking revolution. World over banks are reorienting their business strategies towards new opportunities offered by e-banking. E-banking has enabled banks to scale borders, change strategic behavior and thus bring about new possibilities.

Nepal Bank Ltd. was established in 1937 as the first bank to start banking in Nepal. With the establishment of Nepal Arab Bank Ltd. (now NABIL Bank) in 1984, the first joint venture bank, was the first step towards e-banking in Nepal. It introduced credit cards in Nepal in early 1990 as for the development of e-banking in Nepal. After the establishment of first bank in banking sector Kumari Bank Ltd. was the first to start the internet banking in Nepal in 2002. After ten years of introduction of internet banking, it is still not popular in Nepal. People still rely on traditional ways of banking. Although the major cities like Kathmandu, Pokhara, Biratnagar have good internet facilities and majority of the bank provides the internet banking in urban cities but still internet banking is in its early stage and is not utilized by most of the bank customers. Some Studies show that there are about 200,00o internet users in Nepal, out of which 50 percent users are inside Kathmandu valley. One of the study have found that in terms of e- banking, ATM service is adapted by most of the banks in Nepal, while mobile banking getting the popularity but internet (computer-based) banking is still not available (Banstola, 2007).

This article provides comparisons between the views of different groups of customers and staff regarding e-banking challenges. The findings of this research would be useful for policy makers and bank managers in the formulation of best practice in order to promote e-banking and also aid researchers in studies related to e-banking. E-commerce literature has studied the phenomenon of e-banking from different perspectives. Some research has analyzed the adoption and growth of e-banking, whilst others describe the challenges and benefits to be gained from e-banking services as far as the organization is concerned.

For the past two decades, the banking sector has chosen a new service channel based on the progress of information technology-the Internet- to respond to the changes in customer preferences and needs, increased competition from non-banks, changes in demographic and social trends, and government deregulations of the financial service sector. The adoption of new IT applications is influenced largely by factors related to overall organizational attitudes and culture as well technical and infrastructural elements.

Aladwani (2001) conducted research about the drivers and challenges of online banking; the results of the study show that top bank managers are in support of a lack of internet specialists and changes in Internet technology being the principle issues relevant to online banking development whereas IT managers mentioned time and budget constraints and also immature Internet technology. The study also indicates that according to general and IT managers' technical obstacles are the most 
important challenge for the development of e-banking. Customers however mentioned internet security, online banking regulations and customers' privacy as the most important future challenges of e-banking in Kuwait.

A study carried out by Daniel (2002) concluded that the price of electronic services, increased competition due to new entrants, and trust can be future challenges for banking systems considering e-banking. Khorshid and Ghane (2009) studied and ranked the challenges of e-banking identified for managers of bankscustomers' privacy, security, and customers' trust as issues arising. For customersreputation of bank, regulations and laws, and easy accessibility were seen as the main challenges for the development of e-banking.

Angelakopoulos and Mihiotis (2011) demonstrate that banks expand to e-banking services in order to remain competitive, to keep track with technological developments and to benefit from the lower cost of e-banking transactions. The major problems they face are the low response rate from customers and the implementation of security and data protection mechanisms. The relatively low Internet usage, the non-familiarity with technologically advanced devices and problems regarding security and privacy are the main factors that have a negative influence on the adoption of e-banking services by customers in Greece.

\section{Conceptual model and hypotheses of the study}

A qualitative assessment, using interviews with IT professionals of banks was performed and with the help and review of available studies in this field we conclude that effective factors for implementation and development of e-banking can be divided into two broad groups including soft and hard factors. Soft factors can be; culture, awareness, job and human relations, trust, resistance, coordination, and decision making etc. Hard factors include supporting soft factors with suitable technological and economic infrastructures, finance of network development and the preparation of software and hardware required of e-banking etc. Therefore, from all related factors we conclude that the barriers and challenges of electronic banking in Nepal can be categorized into three main groups, including infrastructural barriers, legal and security issues, and management and banking issues.

After a review of concepts and the relevant literature pertaining to e-banking, research has been organized following a conceptual model that includes all the different barriers to e-banking and has arranged these into three categories.

The hypotheses in this study includes with the bases of three assumptions:

1. Infrastructural barriers are one of the challenges for implementation and development of e-banking in Nepal.

2. Legal and security issues are one of the challenges for implementation and development of e-banking in Nepal.

3. Management and banking issues are one of the challenges for implementation and development of e- banking in Nepal

\section{Methods}

One of the primary concerns of this paper is to identify the important parameters affecting the development of e-banking. To determine the dimensions of e-banking and its challenges, a questionnaire survey was conducted. The questionnaire consists of two parts. The first part comprises 6 questions concerning the demographic profile of the respondents and the second part consists of 36 questions in three specific sections related to different challenges in order to explore the respondent's perceptions about the challenges and obstacles for development of e-banking in Nepal. 
Table: 1 Correlation analysis of challenges and e-banking development

\begin{tabular}{|l|c|c|c|}
\hline \multicolumn{1}{|c|}{ Challenge } & r & sig & $\begin{array}{c}\text { Significant } \\
\text { level }\end{array}$ \\
\hline Infrastructural & -0.072 & 0.311 & 0.05 \\
\hline Legal-Security & -0.234 & 0.001 & 0.05 \\
\hline Management- Banking & -0.151 & 0.033 & 0.05 \\
\hline
\end{tabular}

The questionnaire was first pre-tested amongst bank specialists so as to provide commentary on the relevance and wording of questionnaires' items, length of survey and time taken to complete questions. The population of interest is defined as two groups including bank staff and electronic banking customers and they have been asked for their opinions. In total 200 questionnaires were filled out. The Cronbach's Alpha value was calculated for these questionnaires and it was equal to o.809. The correlation coefficients were calculated to evaluate the relationship between variables. Independent sample $\mathrm{t}$ tests and one way ANOVA and post-hoc tests have been applied to compare the mean scores of different groups of educational attainment and job experience. A Friedmann test was undertaken for ranking purposes.

\section{Results and discussion}

In order to find out the challenges of e-banking development, the hypotheses of the study are tested as follow:

Table: 2 Impact of infrastructural barriers on e-banking according to variables

\begin{tabular}{|c|c|c|c|c|c|c|}
\hline \multicolumn{2}{|c|}{ Variables } & $\begin{array}{c}\text { Frequen- } \\
\text { cy }\end{array}$ & Mean & SD & Test & Sig \\
\hline Education level & $\begin{array}{l}\text { Intermediates } \\
\text { Graduation Post- } \\
\text { graduation }\end{array}$ & $\begin{array}{c}2 \% \\
52.5 \% \\
45 \cdot 5 \%\end{array}$ & $\begin{array}{l}9.0000 \\
9.6190 \\
9.4835\end{array}$ & $\begin{array}{l}0.81650 \\
2.43524 \\
2.54891\end{array}$ & $\mathrm{~F}=0.173$ & 0.842 \\
\hline Job experience & $\begin{array}{l}\text { Less thanio 10-20 } \\
\text { More than } 20\end{array}$ & $\begin{array}{l}25 \% \\
6.5 \% \\
18.5 \%\end{array}$ & $\begin{array}{l}9.7900 \\
10.2308 \\
8.4324\end{array}$ & $\begin{array}{r}2.66351 \\
2.65059 \\
2.44427\end{array}$ & $F=3.654$ & $0.030^{*}$ \\
\hline Position & \begin{tabular}{|l} 
Staff \\
Customer
\end{tabular} & $\begin{array}{l}50 \% \\
50 \%\end{array}$ & $\begin{array}{l}9 \cdot 3200 \\
9 \cdot 7700\end{array}$ & $\begin{array}{l}2.65101 \\
2.24668\end{array}$ & $\mathrm{~T}=-1295$ & 0.197 \\
\hline
\end{tabular}
${ }^{*} p<0.05$ 
Table: 3 Impact of legal and security barriers on e-banking according to variables

\begin{tabular}{|c|c|c|c|c|c|c|}
\hline & Variables & $\begin{array}{c}\text { Frequen- } \\
\text { cy }\end{array}$ & Mean & SD & Test & Sig \\
\hline $\begin{array}{l}\text { Education } \\
\text { level }\end{array}$ & \begin{tabular}{|l|} 
Intermediates \\
Graduation Post- \\
graduation
\end{tabular} & $\begin{array}{c}2 \% \\
52.5 \% \\
45.5 \%\end{array}$ & $\begin{array}{l}17.2500 \\
17.0000 \\
16.5055\end{array}$ & $\begin{array}{l}1.89297 \\
3.29335 \\
3.22235\end{array}$ & $\mathrm{~F}=0.615$ & 0.542 \\
\hline $\begin{array}{l}\text { Job } \\
\text { experience }\end{array}$ & \begin{tabular}{|l} 
Less than 10 \\
$10-20$ \\
More than 20
\end{tabular} & $\begin{array}{l}25 \% \\
6.5 \% \\
18.5 \%\end{array}$ & $\begin{array}{l}16.9400 \\
16.9231 \\
15.8919\end{array}$ & $\begin{array}{l}3.94560 \\
3.25222 \\
2.92293\end{array}$ & $F=3.030$ & $0.041^{*}$ \\
\hline Position & Staff Customer & $\begin{array}{l}50 \% \\
50 \%\end{array}$ & $\begin{array}{l}16.5500 \\
17.0100\end{array}$ & $\begin{array}{l}3.51440 \\
2.90070\end{array}$ & $\mathrm{~T}=-2.977$ & $0.034^{*}$ \\
\hline
\end{tabular}

\section{Correlation analysis of challenges and e-banking development}

Table 1 indicates that there is no correlation betweeninfrastructural barriersande-banking development. Therefore infrastructural barriers are not currently a challenge for the development of e-banking in Nepal. There is a negative correlation between legal and security barriers and e-banking development. It means a null hypothesis is not accepted and legal and security barriers are a challenge for implementation and development of e-banking in Nepal.

\section{Impact of infrastructural barriers on} e-banking according to variables

In order to find out whether there is a difference of views between banks' employees regarding the different challenges of e-banking, an ANOVA test has been used to show whether the level of education and age have any significant impact on the views of banks' employees in India due to general perceptions that old and not so well educated employees have negative observations about e-banking services. Table 2 displays the different groups whom were compared with regard to infrastructural barriers, the results showed there is a meaningful significant difference between staff views of different job experiences at $\mathrm{p}<0.05$. Staffs that have experienced between 10-20 jobs have a greater belief in infrastructural barriers affecting e-banking development and respondents with different educational levels and positions hold a similar view.

\section{Impact of legal and security barriers on e-banking according to variables}

Table 3 reveals that according to the F-value and significance level (3.030, 0.041) there is a statistically significant difference at the $\mathrm{p}<0.05$ level for the three groups of job experience, therefore the Post-hoc test shows staff with less than 10 years' experience, more than others believe that legal and regulation issues have a greater impact on the development of e-banking. In addition the t-value obtained together with the level of significance indicates that the mean difference between the two groups is significant. Therefore, there is a meaningful significant difference between respondent's opinions with regards to legal 
Table 4 Impact of management-banking barriers on the development of e-banking according to variables

\begin{tabular}{|c|c|c|c|c|c|c|}
\hline \multicolumn{2}{|c|}{ Variables } & $\begin{array}{c}\text { Frequen- } \\
\text { cy }\end{array}$ & Mean & S.D & Test & Sig \\
\hline Education level & $\begin{array}{l}\text { Intermediate } \\
\text { Graduation Post- } \\
\text { graduation }\end{array}$ & $\begin{array}{l}2 \% \\
52.5 \% \\
45 \cdot 5 \%\end{array}$ & $\begin{array}{l}16.0000 \\
16.1905 \\
15.9011\end{array}$ & $\begin{array}{l}2.94392 \\
3.30819 \\
2.78510\end{array}$ & $F=0.217$ & 0.805 \\
\hline Job experience & $\begin{array}{l}\text { Less than } 10 \\
10-20 \\
\text { More than } 20\end{array}$ & $\begin{array}{l}25 \% \\
6.5 \% \\
18.5 \%\end{array}$ & $\begin{array}{l}15.5600 \\
16.1538 \\
15.4054\end{array}$ & $\begin{array}{l}3.65424 \\
3.41189 \\
3.23573\end{array}$ & $F=0.225$ & 0.799 \\
\hline Position & Staff Customer & $\begin{array}{l}50 \% \\
50 \%\end{array}$ & $\begin{array}{l}15 \cdot 5800 \\
16.5300\end{array}$ & $\begin{array}{l}3.44709 \\
2.55230\end{array}$ & $\mathrm{~T}=-\mathbf{2 . 2 1 5}$ & $0.028^{*}$ \\
\hline
\end{tabular}

${ }^{*} p<0.05$

and security barriers and customers believe legal and security issues have more impact on e-banking development.

Table 4 indicates that the obtained value of $t$ and level of significance $(-2.215,0.028)$ show that the mean difference between the two groups is significant. Therefore, there is an important difference between respondent's opinions regarding management and banking barriers. Customers believe this obstacle has more impact on e-banking than staff and also the result showed respondents with different education levels and job experience hold similar views.

\section{Conclusion}

The present investigation has shown that legal and security issues and managementbanking issues are accepted as challenges for e-banking development in Nepal. Followed by legal, security issues and managementbanking and infrastructural barriers is the least important according to both staff and customers.
According to the Byers (2001) staff with 10-20 years 'experience, more than others believed infrastructural barriers have a negative impact on e-banking development and staff with less than 10 years' experience, more than others believed that legal and regulation issues have an inappropriate impact on ebanking development. Customers and staff believed that legal and security barriers and management and banking issues have more effect on e-banking development. Therefore, we can highlight for customers security is still a big concern for usage of e-banking services and the view of young and educated staff regarding e-banking is more supportive in Nepal. The study shed light on some important issues related to specification of challenges for development of e-banking that have not been addressed by previous studies. First, in terms of theory and literature this study attempts to provide a model with three factors which almost includes all obstacles and challenges and can be useful for further researches.

This study suggests that decision makers should consider focusing on the trust, 
awareness, and confidence of users by enhancing security features, utilizing proper e-legislation, and the provision of digital receipts or a guarantee for every transaction in order to inspire greater confidence in users of such services and promote a culture of e-banking usage across Nepal.

\section{References}

Angelakopoulos, G, \& Mihiotis, A. (2011). E-banking challenges and opportunities in Greek banking sector. Electronic Commerce Research Journal, $11(3) 297-319$.

Aladwani, A. (2001), online banking: a field study of drivers, development challenges, and expectations. International Journal of Information Management, 21 (2001):213-225.

Banstola, A. (2007). Prospects and challenges of e-banking in Nepal. The Journal of Nepalese Business Studies, 4(1) 213-225.

Basel Committee Report on Banking Supervision. (1998). Risk management for banking and electronic money activities. Retrieved from: www.bis.org/publ/bcbs98 on 13th September, 2015 .
Byers, R. \& Lederer, P. (2001). Retail banking service strategy: a model of traditional, electronic and mixed distribution choices. Journal of Management Information Systems, 18(2):133156.

Daniel, E. (1999). Provision of electronic banking in the UK and the Republic of Ireland. International Journal of Bank Marketing, $17(2): 72-82$.

Khorshid, S. \& Ghane, H. (2009). Ranking the challenges of e-banking with the help of AHP model. Journal of Modiriyate Sanati University of Sanandaj. 4(9) 89-106.

Nisture, R. (2003). E-banking challenges and opportunities. Economic and Political Weekly, 38(9):51-52

Shanmugan, B. \& Guru, B. K. (2003). E-banking in Malaysia. Institute bank-bank Malaysia. 12(7):224-234.

Sathye, M. (1999). Adoption of internet banking by Australian consumers: an empirical investigation. International Journal of Bank Marketing, 17(7):324-334. 